\title{
Határsértések: a tudomány és a politika határán
}

Orosz László: Tudomány és politika. Fritz Valjavec (1909-1960) a két világháború közötti magyar-német tudománypolitikai kapcsolatokban. Budapest, Ráció Kiadó, 2014.

\begin{abstract}
tudománypolitika kutatási témaként a német A történettudományban jobban, ám a magyarban már kevésbé preferált kérdéskör. Ezért is örülhetünk Orosz László nemrég megjelent monográfiájának, amely a két világháború közötti magyar-német tudománypolitikai kapcsolatok jelentős személyiségével, Fritz Valjaveccel és annak magyar tudományos kapcsolatrendszerével foglalkozik. Nagy hangsúlyt kap a tudományosság, ugyanis - mint azt a szerző is megjegyzi - nem Valjavec politikai kapcsolatait célja bemutatni, hiszen annak egy jelentős szegmensét, a Franz Basch-hoz füződő viszonyát Tilkovszky Loránt már feltárta.

A német történettudományra már az 1960-as évektől oly jellemző önkritikus múltfeltárás sajátos színfoltja a Délkelet-Európa-kutatás ${ }^{1}$ személyi és intézményi hátterének a vizsgálata. Ennek nagyobb lendületet az 1990-ben a müncheni Südost-Institut-ban megrendezésre kerülő történészkonferencia adott, hogy aztán ezt követően 1998-ban és 2002-ben is egy-egy konferenciával tovább szőjék a múlt feltárásának a fonalát.
\end{abstract}

\footnotetext{
* A szerző az MTA TK Kisebbségkutató Intézet tudományos munkatársa. E-mail: marchut.reka@tk.mta.hu.

${ }^{1}$ Ennek két világháború közötti jelentősebb központjai a stuttgarti Deutsches Auslandsinstitut (DAI), a müncheni Südost-Institut és a berlini egyetem.
}

REGIO 23. évf. (2015) 3. szám 199-205. 
A szerző megjegyzi, hogy nem születtek „magyar szemléletmódú” értékelések. „A kötet ezt a hiányosságot pótolja, miközben sajátosan magyar szempontrendszertől vezérelve egészíti ki a Délkelet-Európa-kutatás e meghatározó alakjával kapcsolatban az ezredforduló környékén felpezsdülő érdeklödést." (9.) Ez a mondat akarva-akaratlanul azt sugallja, hogy a történetírást nemzeti paradigmák határozzák meg, ami egyfelöl valóban így van, másfelöl azonban ha tudományt müvelünk, akkor annak jellegéből adódóan, a múlt objektivitásához való törekvésünk jegyében nem dolgozhatunk nemzeti szemléletmóddal. Bár a célkitüzés megfogalmazásával a recenzens nem teljesen ért egyet, mégis örömmel állapíthatja meg, hogy a munka valóban tudományos igényü írás, amit nem csak a magyar, hanem a német történetírás is haszonnal forgathat.

Ugyanakkor nem kapunk választ arra, hogy az ezredforduló környékén miért pezsdült fel az érdeklődés a téma iránt. Ennek hátterében minden bizonnyal az Európai Unió motorjának számító, egyre erősebb hatalmi pozícióval bíró Németország politikája és az EU keleti terjeszkedésének a korabeli aktuális problémaköre állhat.

A munka egésze alapos, részletes, sok szempontra kiterjedő levéltári kutatómunka eredménye. Az első része életrajz, mely a magyar és nemzetközi szakirodalomban az első terjedelmes és átfogó Valjavec-biográfiának tekinthető. A könyv második része Valjavec és a magyar tudósok kapcsolataival foglalkozik. A tudománypolitikai kontextust röviden felvázolva az egyes tudományágak szerinti bontásban mutatja be Valjavec magyarországi kapcsolatrendszerét, majd egy esettanulmánnyal, a Mályusz Elemérrel folytatott levelezésen keresztül világossá válik, hogy Valjavec sok esetben a tudományt alárendelte a politikának.

A függelék - több éves szorgos kutatás gyümölcseként Valjavec magyarországi kollégákkal folytatott levelezésének tabelláris felsorolása, ami hasznos bázisul szolgálhat további kutatásokhoz. Az összeállítás a Bayerisches Hauptstaatsarchiv Valjavec-hagyatéka alapján készült, csak Mályusz esetében egészült ki a Magyarországon fellelhető levelekkel. A kötet bevezetőjéből a recenzens hiányolja azt a módszertani részt, amelyben a szerző többek között - választásának szempontjaira is kitérhetett volna.

Nagy értéke a könyvnek a teljes Valjavec-Mályusz levelezés publikálása. Kár, hogy a szerző nem adja meg a források pontos lelöhelyét. Alapvető szerkesztési hiba, hogy a törzsszöveget és a dokumentumokat nem „varrták össze”. További szerkesztési

REGIO 23. évf. (2015) 3. szám 199-205. 
hiányosság, hogy a szövegben előfordulnak újra és újra ismétlődő megállapítások, ám előre- vagy hátrautalás nélkül.

A kötet gazdag bibliográfiával és névmutatóval zárul. Az elöbbi használatát megnehezíti, hogy a Valjaveccel kapcsolatos magyar vonatkozású ismertetések nem ábécérendben, hanem kronologikusan követik egymást.

A valóban sokrétủ bemutatást tovább segíthette volna, ha Orosz László a témáját szélesebb köztörténetbe ágyazza be. A két világháború közötti magyar-német viszony felvillantásával, a Pax Germanica elképzelésekre való utalással Valjavec taktikázásai is mélyebb értelmet kaptak volna, ehhez az eddigi magyar szakirodalomból kellő támpontot lehetett volna meríteni. Ugyanakkor fontosnak tartottuk volna felhasználni azokat az iratokat, amelyek mind magyar részröl (Wilhelmstrasse és Magyarország), mind német részről (Akten zur Deutschen Auswärtigen Politik) már nyomtatásban, utóbbi digitalizált formában is elérhető. Itt példaként csak egyet: amikor 1942/43-as tanév őszi szemeszterében Valjavec szemináriumán parázs vita bontakozott ki az asszimilációról és a disszimilációról, az ügy a berlini magyar követséghez is eljutott. Fontos lett volna bemutatni ennek diplomáciai hátterét.

A kötet első részében szerző a Bécsben született, ám a bánáti Versecen nevelkedett Valjavec életét mutatja be ifjúkorától, tudományos munkásságán keresztül haláláig. A könyv címéből is adódóan a két világháború közötti rész kidolgozottabb, a II. világháború utáni éveket pedig vázlatosabban tárgyalja.

Orosz szerint Valjavec verseci származása miatt a délkeleteurópai német népcsoport tagjának érezte magát. A deutschungar identitás az I. világháború után értelmezhetetlenné vált a szétszóródtatás következtében, ezt váltotta fel a südostdeutsch identitás. A recenzens ellenben azt mondja: a deutschungar identitás, mint a hungarus-tudat része, soha nem volt a magyar államhatárokon belül élő összes német sajátja a betelepült németek történeti gyökereinek különbözősége miatt. Teljesen más identitással rendelkezett az erdélyi szász, a szepességi cipszer és a döntően 18. században betelepült ún. dunai sváb. A deutschungar identitás az I. világháború után valóban élhetetlenné vált, mert a német volksdeutsch identitásnak kevés, a magyar asszimilációs törekvéseknek pedig sok volt. De ennek a deutschungar-tudatnak a helyébe soha nem lépett a südostdeutsch, annak ellenére sem, hogy

REGIO 23. évf. (2015) 3. szám 199-205. 
Berlinből a Südosteuropa-ban élő németséget (bennük a magyarországi németeket is) szerették volna egységesnek tekinteni, a Südostdeutschtum csak Berlinböl létezett, ám a valóságban egységesen soha nem létező népcsoportot jelöl.

A szerzővel ellentétben mondjuk: a verseci gyermekévekből nem féltétlenül kellett az útnak a német identitás felé vezetni. Elegendő csak az 1927-ben megalakult Revíziós Liga elnökére, a verseci származású Herczeg Ferencre gondolnunk.

A budapesti Reichsdeutsche Oberschule-ban töltött évek minden bizonnyal nagyobb identitásképző erővel bírtak, azzal együtt is, hogy tudjuk, több „magyarón” tanár is nevelte az odajáró diákokat. A fejezetben azt olvashatjuk, hogy Valjevec történeti látásmódot kapott ettől az iskolától, méghozzá a „Kárpát-medence múltjának magyar szemléletű interpretációját”. Csakhogy a naher Südost ${ }^{2}$ geopolitikai egységként való látása messze nem a történelmi Magyarország egységben való látását jelentette, hanem sokkal inkább illeszkedett abba a Mitteleuropa-tervbe, ami berlini vezetéssel térségünknek alárendelt szerepet szánt.

A Bleyer Jakabbal való kapcsolat súlyának megfelelően külön fejezetet kap a könyvben, ám ha a Magyarországi Német Népművelődési Egyesület esetében a szerző Bleyer mellett Gratz Gusztáv személyéről is szólt volna, cizelláltabb képet kaphatnánk arról is, hogy Valjavec Bleyer támogatásával ösztöndíjasként Münchenben végezte egyetemi tanulmányait. És itt következik be az a „minőségi változás, amely disszertációja alapkoncepciójában is világosan kiütközik: a térség németségére pillantva DeutschUngartum helyett immáron Südostdeutschtum-ot látott maga elött." (26.) Innen is látszik a Versecről származtatott südostdeutsch identitás valótlansága.

A kötetben találkozunk több alkalommal is Valjavec emberi gyengeségeivel: így amikor szembefordult Helle Ferenccel, a Reichsdeutsche Schule rá nagy hatást gyakorló tanárával, vagy amikor azt a Bleyer Jakabot minősítette le méltánytalanul, aki egykori mestere volt, pályájának nem csak elindítója, hanem annak

\footnotetext{
${ }^{2}$ A korabeli német felfogás szerint a történelmi Magyarország, majd később a trianoni Magyarország is Südosteuropa-hoz, azaz Délkelet-Európához tartozott. De ugyanebben a térségben volt helye a balkáni államoknak is. A naher Südost (közel Délkelet) kifejezés a balkáni térségtől való megkülönböztetést volt hivatott szolgálni.
}

REGIO 23. évf. (2015) 3. szám 199-205. 
haláláig támogatója is. „Nagy népi szerencsétlenségnek tartom, hogy akkoriban Bleyer a <vezérszerepet> magához ragadhatta." - írta az akkor már néhai Bleyer egykori riválisának, Guido Gündischnek 1935-ben. Ugyanakkor 1938 telén a Südost-Forschungen szerkesztőjeként Karl Valentin Müller tanulmányához a következőt füzte: ,[...] számunkra Bleyer neve néppolitikai tőke, s meg kell akadályoznunk mindent, ami a magyarokat arra indíthatná, hogy azt mondják, Bleyer magyar érzelmét immár német részről is elismerik." (86.) És tette mindezt a karrierjében való előrejutás kedvéért.

A kétséget kizáróan művelt és tehetséges ifjú céljai eléréséhez sok mindent felvállalva 1935. október 1 -jétől már a Südost-Institut munkatársa. Ezzel a kiegészítéssel egyetértünk a szerzővel, amikor megállapítja: „Az üstökösként felfelé ívelö karrier kiépítésében vitathatatlan rátermettsége, tettereje, szervezőkészsége és szorgalma mellett fontos szerepet játszottak az egyetemi évei óta aktívan ápolt népiségi és nemzetiszocialista kapcsolatai is." (44.) 1933-ban belépett az NSDAP-be és az SS-be is. Ez utóbbiból valószínüsíthetően 1935-ben kilépett.

A II. világháború ideje alatti tevékenységéröl keveset tudunk meg. A berlini egyetemen való oktatómunka áll a középpontban, ahol Valjavec 1945-ig taníthatott. A háború után berendezkedő új rendszerben azonban majd egy évtizedig ellenőrzés alatt tartották, oktatói megbízást újra majd csak 1954-ben kapott a müncheni egyetemen, a Südost-Institut élére pedig 1955-ben került vissza. ${ }^{3}$ Mivel Orosz az esettanulmányban a Mályusszal való kapcsolattal foglalkozik, kívánatos lett volna Mályusz és Valjavec 1945 utáni pályáját párhuzamba állítani. Ha elmondjuk, hogy Mályusz, bár oktatói megbízatást nem kapott, de 1955-ben már az MTA Történettudományi Intézetének a fömunkatársa, akkor a hazai történettudomány helyzetét is egy szélesebb kontextusban tudjuk értékelni.

Valjavec 1945 utáni tudományos tevékenységének a vizsgálata időben túlmutat a szerző célkitűzésén, ám az érdeklődő olvasó a Délkelet-Európa-kutatás alakulását és benne Valjavec szerepét is továbbkövetheti a könyvben. Ebben megtaláljuk a magyar témákkal való foglalkozás visszaszorulását, az 1960-70-es években - Valjavec halálát követően - viszont a kelet-európai történelem mint oktatási és

\footnotetext{
${ }^{3}$ Tilkovszky Loránt szerint 1951-ben. L. Tilkovszky Loránt: Fritz Valjavec és a magyarországi németség (1935-1944). In: Századok, 1993, 3. szám, 601.
}

REGIO 23. évf. (2015) 3. szám 199-205. 
kutatási terület újra figyelmet kap. Az eköré egy-két mondattal rajzolt nagypolitikai változások ezeket a folyamatokat magyarázhatták volna meg.

A recenzens a munka legjobban megírt részének a második föfejezetet tartja, amelyben a szerző Valjavec és a magyar tudományos élet kapcsolatát vizsgálja. Orosz itt túllép az előző rész többnyire leíró stílusán, és egy szélesebb tudománypolitikai kontextusba helyezve, több alkalommal szintetizáló megjegyzésekkel mutatja be Valjavec és az egyes tudományágak magyarországi müvelői közötti kapcsolatokat. Ezeken keresztül nagyon szemléletesen feltárulnak azok a taktikázások, amelyeket Valjavec alkalmazott a német tudománypolitikai célok - és tegyük hozzá: saját önérvényesítése - érdekében.

Számunkra különösen fontos a magyar történettudománnyal való kapcsolat. A Szekfü-Mályusz közötti ellentétet meglovagolni akaró Valjavec a „két rivális erkölcsi tartása és szakmai felelősségérzete miatt" csak mérsékelt sikereket tudott elérni, holott nagyon törekedett a belső törésvonalak kiaknázására. Az 1930-as évek elején Valjavec számára még Szekfü Gyula volt fontos, ám a 30-as évek végére, amikor Szekfü egyre inkább hangot adott a fenyegető német veszélynek, Szekfü helyére Valjavec szemében Mályusz lépett. „[A]z 1930-as évek elején Valjavec még Mályusz szakmai kompetenciáját vonta kétségbe" - olvashatjuk a könyvben (149.) Ám ha arra gondolunk, hogy ekkor veti papírra Vörös emigráció címü munkáját a Napkeletben, akkor talán némi alapja volt Valjavec viszonyulásának az akkori Mályuszhoz. Azzal együtt is, hogy úgy gondoljuk, Mályusz akkor is jó szakember volt miközben megtette a gesztust a kurzus felé.

Míg az 1935-ben induló Südostdeutsche Forschungen első számában megjelenő Szekfü-tanulmány még komoly nemzetközi legitimációs bázist jelentett Valjavecnek, Mályuszt máris a SzekfüHóman tollából megszülető magyar szintézis bírálatára kérte fel. Mályusz azonban a küzdelmet nem a német lap hasábjain akarta megvívni.

A Valjavec-Mályusz levelezést elemezve a szerző érzékletesen tárja az olvasó elé ennek a kapcsolatnak a nagyon érzékeny, bizalmatlansággal terhelt voltát. Az egymás iránti empátia csak ,,a végső bukás árnyékában tudott igazán emberi hangot ölteni”, ám ebben a recenzens nem az emberi minőség megváltozását, hanem a történelem alakulásának sokszor sorsfordító szerepét látja.

REGIO 23. évf. (2015) 3. szám 199-205. 
A könyvben sajnálatos módon nincs összegző fejezet, ám a bevezetőben olvashatunk összegző megállapításokat. E szerint Valjavec életútja egy hárompólusú erőmező függvénye: a szakmai korrektség, a hitleri Németországhoz való elköteleződés, a bánáti és südostdeutsch gyökerekhez való „mindvégig lojális Landsmann patriotizmus". "Ezt annyival egészítenénk ki, hogy a szakmai korrektséget több alkalommal felülírta a hitleri Németországhoz való elköteleződés.

„Úttörő jelentőségü volt az a kísérlet, hogy lapja európai fórumot teremtett az érintett népek gyakran homlokegyenest eltérő nézeteinek kifejtésére, s ezáltal a két világháború közötti időszak kölcsönös sértődöttségének feloldására. Még akkor is elmondható mindez, ha e tudományos polémiák kontrollált mederbe terelést (vagyis az eredeti célkitüzése szerint a német kultúrfölény igazolására létrehozott Südost-Forschungen hasábjain történő lefolytatását) Valjavec nyilvánvalóan a kor német tudománypolitikai céljainak szolgálatában tette." - írja Orosz (8-9.) Szerintem a hangsúly a másodikon van, hiszen a kötetben hosszasan sorolja azokat a taktikázásokat, amelyekkel Valjavec a különböző származású és különböző nézőpontot képviselő tudós kollégáit egymás ellen kijátszotta.

Orosz László könyve vitathatatlanul fontos a két világháború közötti magyar-német tudománypolitika iránt érdeklődők számára. Mind a laikus olvasók, mind a történészek haszonnal forgathatják, és ez utóbbiakat további kutatásokra inspirálhatja. Nagyon lényeges üzenetnek tartjuk: „Valjavec ismételt felkéréseire sem voltak hajlandóak [ti. Szekfü és Mályusz - a szerz. megj.] a külvilág elé tárni a magyar történésztársadalmat megosztó belső frontvonalakat." (139.) Ez mindannyiunk számára követendő példa.

${ }^{4}$ A Landsmann patriotizmus itt annak a jelenségnek a leírására szolgál, hogy Valjavec lojalitása, hazaszeretete elsősorban a bánáti vidékhez, ahhoz a tájegységhez köthető, tehát nem az államhoz.

REGIO 23. évf. (2015) 3. szám 199-205. 